University of Rhode Island

DigitalCommons@URI

Civil \& Environmental Engineering Faculty

Publications

Civil \& Environmental Engineering

2020

\title{
Abatement of circumneutral mine drainage by Co-treatment with secondary municipal wastewater
}

Charles D. Spellman Jr.

University of Rhode Island

Travis L. Tasker

William H.J. Strosnider

Joseph E. Goodwill

University of Rhode Island, goodwill@uri.edu

Follow this and additional works at: https://digitalcommons.uri.edu/cve_facpubs

The University of Rhode Island Faculty have made this article openly available.

Please let us know how Open Access to this research benefits you.

This is a pre-publication author manuscript of the final, published article.

Terms of Use

This article is made available under the terms and conditions applicable towards Open Access

Policy Articles, as set forth in our Terms of Use.

Citation/Publisher Attribution

Spellman, C. D., Jr., Tasker, T. L., Strosnider, W. H.J., \& Goodwill, J. E. (2020). Abatement of circumneutral mine drainage by Co-treatment with secondary municipal wastewater. Journal of Environmental

Management, 271, 110982. doi: 10.1016/j.jenvman.2020.110982

Available at: https://doi.org/10.1016/j.jenvman.2020.110982

This Article is brought to you for free and open access by the Civil \& Environmental Engineering at DigitalCommons@URI. It has been accepted for inclusion in Civil \& Environmental Engineering Faculty Publications by an authorized administrator of DigitalCommons@URI. For more information, please contact digitalcommonsgroup@uri.edu. 


\section{Abatement of Circumneutral Mine Drainage by Co-treatment}

2 with Secondary Municipal Wastewater

3 Charles D. Spellman Jra, Travis L. Taskerb, William H.J. Strosniderc, Joseph E. Goodwilla*

4 a Department of Civil and Environmental Engineering, University of Rhode Island, Kingston, RI, 02881 USA

5 b Department of Environmental Engineering, Saint Francis University, Loretto, PA 15940 USA

$6{ }^{\mathrm{c}}$ Belle W. Baruch Marine Field Laboratory, University of South Carolina, Georgetown, SC 29440 USA

8 * Corresponding Author at: Fascitelli Center for Advanced Engineering, 2 East Alumni Ave, Room 260,

9 Kingston, RI 02881 USA. E-mail address: goodwill@uri.edu

11 Abstract

12 Acid mine drainage (AMD) is a persistent and problematic source of water pollution. Co-

13 treatment with municipal wastewater (MWW) at existing wastewater treatment plants

14 (WWTPs) has several advantages; however, potential impacts on downstream

15 physicochemical and biological processes are not completely known. This bench-scale

16 study examined the impact of co-treatment by combining a mild AMD at various ratios with

17 MWW, followed by sludge settling and supernatant comparative analysis by a variety of

18 effluent water quality parameters. These measurements were combined with carbonate

19 system and adsorption isotherm modeling to elucidate the mechanisms underlying the

20 experimental results. AMD addition decreased $\mathrm{MWW}$ effluent $\mathrm{PO}_{4}{ }^{3-}$ concentrations by up to

$2190 \%$, demonstrating co-treatment as a low-cost solution for MWW nutrient removal.

22 Coagulation from metals in $\mathrm{AMD}$ was incomplete due to $\mathrm{PO}_{4}{ }^{3-}$ adsorption, confirmed by

23 comparing experimental results with Langmuir isotherm behavior. Sweep flocculation was

24 the dominating particle aggregation mechanism, and co-treatment led to improved particle

25 clarification outcomes. Carbonate system modeling adequately explains pH effects, and can 
26 also be applied to varying AMD matrices. The impact of AMD addition on the MWW

27 microbial community was also investigated which provided evidence of microbial

28 adaptation. This study demonstrates post-aeration co-treatment enables mitigation of mild

29 AMD without adversely affecting WWTP processes. Reported results also frame required

30 future studies to address extant questions prior to full-scale adaptation.

\section{Highlights}

33 - Addition of mild AMD to a secondary wastewater treatment processes examined

34 - Co-treatment removed $>90 \%$ of $\mathrm{PO}_{4}{ }^{3-}$ in wastewater via adsorption

Acid Mine Drainage; Co-treatment; Phosphate adsorption; Iron; Oxygen demand

- Coagulation of iron particles incomplete, dominated by sweep flocculation

- Secondary settling improved at highest drainage dosages

- Minor impact to microbial oxygen consumption rates, with adaptation noted.

8

\section{Keywords}

0

\section{Introduction}

44 mining activity (Johnson, 2003). AMD is generated when mining exposes pyrite rock $\left(\mathrm{FeS}_{2}\right)$

45 to water in the presence of oxygen, thus facilitating pyrite oxidation and producing waters 46 with elevated acidity and dissolved metals (Akcil and Koldas, 2006; Evangelou and Zhang,

47 1995; Ziemkiewicz et al., 1997). Metals of concern vary geographically and often include 48 iron (Fe), aluminum (Al), manganese $(\mathrm{Mn})$, copper $(\mathrm{Cu})$, zinc $(\mathrm{Zn})$, and lead $(\mathrm{Pb})(\mathrm{Jacobs}$ et 
49 al., 2014). Climatic change, such as decreases in seasonal snow pack, can also worsen

50 mineral acidity (Todd et al., 2012). Methods for treating AMD include both passive and

51 active approaches. Passive treatment utilizes calcite rock dissolution, constructed

52 wetlands, and/or biological sulfate reduction (Hedin et al., 1994; Johnson and Hallberg,

53 2005; Watzlaf et al., 2004). Active AMD treatment utilizes addition of alkaline chemicals or

54 oxidants (Goodwill et al., 2019; Singer and Stumm, 1970) and ongoing energy inputs for

55 pumping, mixing, and/or aeration (Coulton et al., 2003; Mitsch and Wise, 1998). There are

56 several additional options for co-treating AMD with other waste streams, including the use

57 of organic solid waste substrates or flowback water produced from hydraulic fracturing

58 (Chang et al., 2000; He et al., 2016). Although these co-treatment options improve water

59 quality, disadvantages exist including the need for construction of treatment infrastructure

60 (e.g. wetlands or limestone beds) or perpetual process inputs (e.g. active treatment). These

61 requirements present difficulties for AMD treatment in economically and/or geographically

62 isolated areas.

63 A novel approach for AMD mitigation is co-treatment with municipal wastewater

64 (MWW) in existing wastewater treatment plants (WWTPs). Co-treatment is the

65 combination of AMD and MWW waste streams, turning one into a resource, best utilizing

66 extra WWTP capacity, and further leveraging existing infrastructure and energy inputs.

67 Declining industrial activity and urban population shifts has resulted in "shrinking cities"

68 for some North American municipalities with historical industrial centers (Rybczynski and

69 Linneman, 1999; Schilling and Logan, 2008). This population loss, combined with water

70 conservation efforts has decreased overall domestic sewage production and increased

71 financial stress on utilities (Faust et al., 2016). As a result, these WWTP have extra 
72 treatment capacity (Dominguez and Gujer, 2006). Co-treating MWW with AMD makes use

73 of this extra capacity and may ultimately improve MWW treatment, while simultaneous

74 mitigating the ecological impact from AMD on receiving water.

Both AMD and MWW pose serious risks to the environment if inadequately treated.

76 Eutrophication is a problem in surface waters, globally (Dodds and Smith, 2016; Smith,

77 2003). Nitrogen and phosphorus present in MWW can cause eutrophication in downstream

78 receiving waters (Harper, 1992). Co-treatment offers WWTPs a low-cost nutrient

79 management approach utilizing another waste stream. The addition of Fe-based coagulants

80 is a relatively common approach to nutrient removal in these situations, and AMD co-

81 treatment presents a primary beneficial use of this otherwise problematic waste (de-

82 Bashan and Bashan, 2004). AMD discharges to surface waters also degrade water quality

83 by acidification and increased metal loadings which pose risks to aquatic ecosystems

84 (Azapagic, 2004; Gray, 1998). The co-treatment of AMD and MWW can remove metals from

85 low pH AMD while also decreasing effluent biochemical oxygen demand (BOD) and

86 Phosphorous (P) in higher pH MWW (Hughes and Gray, 2013a; Strosnider et al., 2013,

87 2011). AMD can also decrease fecal bacteria counts from a MWW discharge when mixed in

88 situ (i.e. within a stream) under low-flow conditions (Kruse et al., 2019).

The effectiveness of passive MWW and AMD co-treatment utilizing specific,

90 additional infrastructure has been quantified across several scales. Bench-scale treatment

91 wetlands with clarification, biofilm media, and limestone beds have also effectively co-

92 treated AMD and MWW by removing BOD and dissolved metals from the combined

93 wastewaters (Strosnider and Nairn, 2010; Winfrey et al., 2010). In other bench-scale

94 studies, sludge from an active AMD treatment plant was mixed with synthetic and raw 
95 MWW effluent at several ratios to determine the potential for enhanced P removal, yielding

96 over 90\% P removal and residual P levels below $0.5 \mathrm{mg} / \mathrm{L}$ (Ruihua et al., 2011; Wei et al.,

97 2008). Field-scale research has included the addition of AMD to an evaporation pond for

98 MWW, which increased solution $\mathrm{pH}$ and removed metal and sulfate concentrations from

99 the wastewaters during 18 months of monitoring (McCullough et al., 2008). A large pilot-

100 scale aerobic wetland, one of the first attempts to treat an AMD discharge with poorly

101 treated secondary MWW, removed Fe (> 60\%) and BOD (> 30\%) well beyond system

102 design expectations (Johnson and Younger, 2006). The first full-scale co-treatment wetland

103 provided evidence that water quality improved with co-treatment increasing $\mathrm{BOD}, \mathrm{NH}_{3}-\mathrm{N}$,

$104 \mathrm{Fe}$, and total P removal during a four-year monitoring period (Younger and Henderson,

105 2014). Although successful, these examples of co-treatment still require establishment of

106 new treatment infrastructure and do not adequately inform the feasibility of direct co-

107 treatment within an existing WWTP.

The addition of AMD to any portion of a conventional activated sludge treatment

109 system poses risks to the biological treatment phase, however, data quantifying these

110 potential impacts is limited. An influx of AMD constituents (e.g. metals, trace organics)

111 could impact microbial community survival, taxonomy, and/or oxygen utilization rates

112 (Ong et al., 2010; Ren and Frymier, 2005; Yuan et al., 2015). Although Fe is a crucial

113 element for growth in nearly all biological organisms, large fluxes of Fe can be detrimental

114 to microorganisms (De Freitas and Meneghini, 2001). The use of Fe-based coagulants in

115 activated sludge systems can impact microbial metabolism, decrease nitrification, and

116 degrade floc formation due to elevated Fe(III) content (Clark et al., 2000). This decreased

117 suspended solids removal is a function of excessive filamentous bacteria growth, a problem 
118 that frequently plagues conventional MWW treatment facilities (Sezgin et al., 1978).

119 Similarly, Fe(III) concentrations of $\sim 100 \mathrm{mg} \mathrm{Fe} / \mathrm{L}$ in activated sludge can inhibit overall

120 microbial activity and nitrification (Philips et al., 2003) However, at lower Fe additions (25

$121 \mathrm{mg} \mathrm{Fe} / \mathrm{L}$ ), microbial activity and nitrification were not inhibited but less stable flocs were

122 observed (Oikonomidis et al., 2010). In a simultaneous nitrification, denitrification, and P

123 removal process, high Fe(III) concentrations can decrease $\mathrm{N}$ removal, but this inhibition

124 can be adapted to and recovered after four, 270-minute cycles (Jia et al., 2016).

125 Furthermore, Deng and Lin (2013) demonstrated co-treating prior to an anaerobic

126 biological treatment step can maintain system performance, completely remove $\mathrm{PO}_{4}{ }^{3-}$

127 under certain conditions, increase alkalinity, and consistently decreasing COD by $>60 \%$.

128 Only one study has focused on AMD and MWW co-treatment in a conventional

129 activated sludge system (Hughes and Gray, 2013b). Hughes and Gray (2013) examined

130 several different options for co-treatment including (1) the addition of untreated AMD to

131 aeration tanks, (2) the pretreatment of AMD by mixing with digested sewage sludge

132 followed by sedimentation and then mixing in the aeration tank, and (3) the pre-treatment

133 of AMD by mixing with screened MWW prior to treatment in the aeration tank. In all of

134 these experiments, a synthetic AMD was made to simulate the chemistry from copper

135 mines in Ireland ( $\mathrm{pH} 3.6, \mathrm{Fe}=130 \mathrm{mg} / \mathrm{L}, \mathrm{Al}=150 \mathrm{mg} / \mathrm{L}$, and $\left.\mathrm{SO}_{4}{ }^{2-}=1670 \mathrm{mg} / \mathrm{L}\right)$. Systems

136 co-treating with MWW remained effective at removing metals and COD by precipitation

137 and adsorption mechanisms in the activated sludge reactors. In the co-treatment

138 experiments, the synthetic AMD was mixed with synthetic MWW at a 1:2 AMD:MWW

139 volumetric ratio. Metal removal by adsorption was relatively high in all experimental

140 configurations, averaging $52-84 \%$ for $\mathrm{Al}$ and $74-86 \%$ for Fe. Final effluent COD 
141 concentrations were generally less than $50 \mathrm{mg} / \mathrm{L}$ for all treatment configurations but

142 increased on the last sampling event in experiments where AMD was pretreated before

143 addition to aeration reactors. This project concluded that co-treatment did not cause a

144 significant decrease in, nor improve, system performance for the removal of COD, total

145 organic carbon (TOC), or BOD compared to controls, but did improve P and metals removal.

146 Additional work by Hughes and Gray (2012) used Activated Sludge Respiration Inhibition

147 Tests (Organization for Economic Cooperation and Development Method 209) to show that

148 activated sludge systems could adapt to and function with AMD additions as high as 50\%

149 by volume.

150 The strength of the AMD utilized in co-treatment systems may have major process

151 implications. Many of the aforementioned studies examined co-treatment utilizing a

152 narrow range of strong AMD ( $\mathrm{pH}$ range 2-4.5), neglecting potential impacts when utilizing

153 milder ( $\mathrm{pH}>4.5$ ) Class I AMD (as defined by Watzlaf et al., 2004). Class I AMD may make

154 up $>50 \%$ of discharges in the eastern United States (Herlihy et al., 1990), with the vast

155 majority in Northern Appalachia (Watzlaf et al., 2004). Mild or circumneutral discharges

156 are not a localized phenomenon and may also be found in the mid-western United States

157 (Labrenz and Banfield, 2004), Southern Africa (Madzivire et al., 2011), the United Kingdom

158 (Warrender et al., 2011), and certain regions of China (Feng et al., 2014). These mild AMD

159 discharges may be more conducive for co-treatment having bulk water qualities (e.g., pH,

160 alkalinity, etc.) more similar to MWW.

161 The small quantity of data on co-treatment with mild AMD in WWTPs leaves many

162 unanswered questions regarding the physicochemical and biological processes within an

163 existing WWTP. Also, the variability of AMD water quality leaves the opportunity for novel 
164 co-treatment developments utilizing AMD of various water chemistry. The overarching

165 objectives of this study were to quantify the water quality impacts of co-treating

166 circumneutral AMD with secondary MWW MLSS and elucidate the underlying mechanisms.

167 There are many locations within a WWTP where AMD could be added, however the

168 presented study addresses mixing AMD post aeration basin and prior to secondary settling

169 (Figure S1). Laboratory work included bench-scale experimentation with robust water

170 quality analysis, in conjunction with water quality modeling. In order to fill known research

171 gaps, specific project aims included: (1) assessing changes in overall water quality, (2)

172 evaluating coagulation potential from AMD-sourced $\mathrm{Fe}$, (3) demonstrating enhanced $\mathrm{PO}_{4}{ }^{3-}$

173 removal, and (4) characterizing the impact on MWW microbial metabolism. Results of this

174 study advance co-treatment towards potential full-scale adaptation within existing

175 WWTPs.

176

177 2. Materials \& methods

178 A graphical representation of the overall analytical procedure is shown in Figure S2.

AMD was collected from an abandoned mining site near the core of a city with

182 declining population and industrial activity (Johnstown, PA; see Figure S3). Historic water

183 quality for the mild AMD includes a slightly acidic pH (average $\mathrm{pH}=6.1$ ) and averages 85

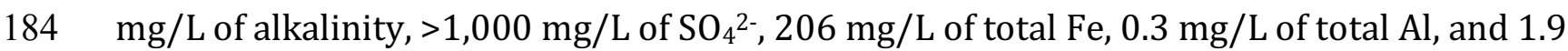

$185 \mathrm{mg} / \mathrm{L}$ of total Mn. The mild AMD has relatively low acidity, which is typical of AMD found in 186 coal mining regions in eastern North America (Hedin et al., 1994). AMD samples were 
187 collected immediately downstream from the AMD discharge pipe. This low-pH, high-Fe

188 AMD source was selected due to its proximity to a situationally-relevant (i.e. shrinking

189 cities) WWTP. MWW were collected from a conventional WWTP (average flow = 10 MGD)

190 at the same time of AMD collection. Mixed liquor suspended solids (MLSS) was collected

191 from the WWTP aeration tank effluent, prior to the secondary clarifiers and used to

192 represent "MWW" samples. The MLSS samples were mixed to prevent the sludge from

193 becoming anoxic. Raw AMD and MLSS (MWW) samples were collected headspace free in

194 collapsible five-gallon polyethylene containers. Methods for examining the impacts on a

195 microbial community are presented in Section 2.4.

2.2. Experimental design

Bird). Eight different sample matrices were tested. MWW MLSS was mixed with either AMD or deionized water (DI) at ratios of 1:25, 1:15, and 1:5 (AMD:MWW; DI:MWW) in addition to $100 \%$ AMD-only and $100 \%$ MWW-only as controls. Ratios were chosen based on

202 practical estimates of extra treatment capacity. All experiments were performed in

203 triplicate. Quality control experiments utilized DI water in place of AMD to address

204 potential dilutive effects from AMD. Samples were mixed for five minutes at G $120 \mathrm{sec}^{-1}$

205 to simulate the two waste streams rapidly mixing in a pipe. They were subsequently

206 allowed to settle for 30 min, representing final clarification (Standard Method 2710D,

207 APHA, 2012). After settling, the top 1 L of supernatant, representing a secondary settling

208 effluent, was decanted into a borosilicate glass beaker. The supernatant beakers were

209 placed on stir plates and mixed while sub-samples for further analysis were collected. 
$211 \quad 2.3$. Supernatant analysis

212 The settled sludge blanket height was recorded prior to the supernatant being

213 decanted. Supernatant $\mathrm{pH}$ values were determined immediately (Mettler-Toledo LE438

214 ATC probe/FiveEasy Plus FP20 meter). Sample turbidity was determined using a portable

215 turbidimeter (Hach, 2100Q) following EPA method 180.1 (via Hach method 8195).

216 Streaming current (a method for quantifying suspended particle surface charge in situ;

217 (Dentel et al., 1989)) was determined using a laboratory charge analyzer (Chemtrac LCA218 01).

219 COD was determined for each sample by the reactor digestion method using Hach

220 low range COD vials according to Hach Method 8000. Vials were digested in a digital

221 reactor block (Hach, DRB200) and analyzed using a UV-Vis spectrophotometer (Hach,

222 DR6000). BOD was determined by the 5-day BOD test performed at $20^{\circ} \mathrm{C}$ (Standard

223 Methods 5210B). Three BOD bottles were collected per beaker at varying dilutions.

224 Dissolved oxygen concentrations were collected using an optical BOD probe (YSI Pro

225 Series) with a multiparameter meter (YSI Pro Plus).

226 Anion samples for $\mathrm{NO}_{3}{ }^{-}, \mathrm{SO}_{4}{ }^{2-}$ and $\mathrm{PO}_{4}{ }^{3-}$ were collected in amber glass vials, filtered

227 through $0.45-\mu$ m nylon filters, and analyzed within 24 hours on an ion chromatograph

228 (Dionex ICS-1100) with an AS18 column following EPA method 300.

229 Samples for solids content were collected in $1000 \mathrm{~mL}$ HDPE bottles and stored at

$2304{ }^{\circ} \mathrm{C}$ for later analysis. Total solids (TS) were determined by evaporating $100 \mathrm{~mL}$ overnight

231 for 10-12 hours in pre-dried and pre-weighed $150 \mathrm{~mL}$ Erlenmeyer culture media flasks at

$232103{ }^{\circ} \mathrm{C}$ (Standard Methods 2540). Total dissolved solids (TDS) were determined in a similar 
233 manner with the exception that a $50 \mathrm{~mL}$ sample volume was filtered through $0.45-\mu \mathrm{m}$

234 nylon filters (Fisher).

235 Samples for $\mathrm{Fe}, \mathrm{Al}$ and Mn were collected in metals-free Nalgene LPDE bottles and 236 preserved to $2 \%$ with trace metal grade $\mathrm{HNO}_{3}$. $\mathrm{Fe}, \mathrm{Al}$, and $\mathrm{Mn}$ were selected due to their

237 relative geographic abundance in AMD discharges. For each beaker, metals concentrations

238 were fractionated with various filter pore sizes to quantify the relative size distribution of

239 resulting particles under each condition (Carlson et al., 1997; Goodwill et al., 2015).

240 Fractionated particles were operationally defined as total, colloidal or dissolved. The total

241 particulate metals were unfiltered and colloidal metals were filtered $0.20-\mu$ m nylon filters,

242 and each sample was collected in triplicate. Two samples per experimental water matrices

243 (i.e. two for each tested ratio \& control) were also filtered through $30 \mathrm{kDa}$ ultrafiltration

244 (UF) membranes inside a $200 \mathrm{~mL}$ nitrogen pressurized stirred UF cell (Amicon). Total

245 metal samples were digested in a digestion/extraction microwave system (CEM, Mars 6)

246 according to EPA method 3015A. Metals concentrations were then quantified using an

247 inductively coupled plasma mass spectrometer (ICP-MS) (Thermo Scientific X-Series 2)

248 measuring isotopes Fe-57, Al-27 and Mn-55. While Fe speciation was not quantified,

249 thermodynamics at equilibrium under test conditions suggest the primary species to be $250 \mathrm{Fe}(\mathrm{III})$.

\subsection{Cellular respiration}

253 Cellular respirometric oxygen demand (i.e. respirometry) was used to assess the

254 impact of AMD on the microbial community within an activated sludge system (Scaglione et 255 al., 2008). Respirometer experiments compared the microbial oxygen uptake between a 
256 control aeration mixed liquor sample to a co-treated sample containing synthetic AMD at a

257 ratio of 1:15. Aeration tank mixed liquor samples (MLSS $=4,670 \mathrm{mg} / \mathrm{L}$, data obtained from

258 WWTP operations report at time of collection) were collected at the Mattabassett District

259 Water Pollution Control Facility (Cromwell, CT), a conventional aeration MWW treatment

260 facility. Synthetic AMD was generated in the lab to replicate the batch study AMD using

261 ultrapure deionized water and dosed to an Fe content of $200 \mathrm{mg} / \mathrm{L}$ using a $1000 \mathrm{mg} / \mathrm{L} \mathrm{Fe}$

262 standard solution (in $3 \% \mathrm{HCl}$ ) and initial $\mathrm{pH}$ adjusted to $\sim 6$ with $\mathrm{NaOH}$ and $\mathrm{H}_{2} \mathrm{SO}_{4}$

263 (Karapanagioti and Atalay, 1996).

264 Trials were performed in specialized, air tight $250 \mathrm{~mL}$ sample bottles (Xylem WTW,

265 MF45). Each bottle was equipped with a $\mathrm{CO}_{2}$ absorbent quiver, filled with $\mathrm{NaOH}$ pellets

266 (98\%, Fisher Chemical) to absorb $\mathrm{CO}_{2}$ gas during experimentation, and sealed with a

267 calibrated WTW OxiTop-C measuring head. Each sample was run in triplicate. The samples

268 were continuously mixed for 4 hours to simulate the hydraulic retention time of typical

269 aeration tanks (Ten State Standards, 2014). Results were gathered using the OxiTop OC100

270 controller and data was reported in mg/L of BOD (Spanjers and Vanrolleghem, 1995).

271

272 2.5. Statistical presentation of data

273 All reported values represent the mean of triplicate experimental replicates. All error

274 bars represent the 95\% confidence interval (2 standard deviations $(\sigma)$ ), unless otherwise

275 noted. Within each triplicate, any individual value that was more than $3 \sigma$, or outside the

$27699.7 \%$ confidence interval (Pukelsheim, 1994) from the mean was considered an outlier.

277

$278 \quad$ 2.6. Water quality modeling 
Iron speciation, $\mathrm{pH}, \mathrm{PO}_{4}{ }^{3-}$ were modeled to further understand the impacts of cotreatment, and elucidate mechanisms underlying laboratory measurements. The influence

281 of varying AMD acidity on $\mathrm{pH}$ was examined by calculating the alkalinity and total $\mathrm{H}^{+}$that

282 would result from mixing AMD of several pH's with pH 6.7 MWW, under open-system

283 carbonate buffering conditions (Stumm and Morgan, 1996), using Equation S5. Changes in

$284 \mathrm{PO}_{4}{ }^{3-}$ concentration were used to create an adsorption isotherm, in a manner similar to

285 Yang et al. (2006). Experimental data was fitted to the Langmuir isotherm (see SI S5,

286 Equation S7) where a high ( $>0.95)$ linear coefficient of determination would indicate

287 adsorption as the primary mechanism. The resulting regression also allowed for the

288 determination of the maximum adsorption capacity under tested conditions. It was

289 assumed experimental mixing and settling was sufficient for the adsorption reaction to

290 reach equilibrium. Fe speciation resulting from co-treatment was determined by combining

291 applicable $\mathrm{pK}_{\mathrm{s}}$ values (Stumm and Morgan, 1996) with empirical models for Fe stability

292 and coagulation (Johnson and Amirtharajah, 1983). This allowed further assessment of

293 dominate coagulation mechanisms.

\section{3. Results \& Discussions}

296 3.1. Supernatant water quality

297 Figure 1 reports impacts of AMD's on general supernatant water quality

298 characteristics. Co-treating had little influence on pH (Figure S4). All pH values were above

299 6.0, a typical Environmental Protection Agency (EPA) National Pollutant Discharge

300 Elimination System (NPDES) permit limit for MWW facilities (Environmental Protection

301 Agency, 2019; EPA Region 3, 2016). The negligible pH change in this study is attributed to 
302 relatively low acidity and high pH of the AMD. Measured results closely follow the modeled 303 pH (Figure S4).



305 Figure 1: Sample turbidity (bars) and streaming current surface charge (points). Dashed 306 line represents trend between experimental data points. Higher strength AMD than the matrix used in this work could still be feasible in cotreatment. Alkalinity and $\mathrm{pH}$ modeling results show that co-treating at 1:25 with AMD of a $309 \mathrm{pH}$ as low as 2.7 would still leave MWW (with a similar pH and alkalinity to experimental 310 MWW) effluent above discharge minimums of pH 6.0 (Figure S4). Mild AMD with a pH 311 similar to that of AMD used in this study could theoretically be used up to AMD:MWW

312 ratios beyond 1:1 whereas co-treatment with stronger AMD of $\mathrm{pH} 3.0$ could likely not

313 exceed 1:25. Moderate strength AMD at a pH of 4.0 could still be feasible for co-treatment

314 at ratios up to 1:3 where the mixed $\mathrm{pH}$ would remain above the target minimum, $\mathrm{pH}$ 6.0.

315 These modeled results are in agreement with co-treatment performed with lower pH AMD 316 (Deng and Lin, 2013). 
No significant difference in AMD nor DI supernatant turbidity relative to the MWWonly (MLSS) control was noted (Figure 1). Although all co-treated turbidity values were

319 statistically similar to each other (within $2 \sigma$, see section 2.5 ), the averages appear to trend 320 upwards with higher values of AMD resulting from the relatively high turbidity of the AMD-

321 only control. The turbidity trends of the co-treated trials agree with predictions from a 322 simple mass balance on TSS (turbidity of AMD added with turbidity of MWW at each ratio, 323 Equation S7). The similarity of settled turbidity values across all experiments indicates a 324 stable colloidal suspension.

325 The addition of positively charged hydrolyzed Fe (and Al) species from AMD could serve as a coagulant and destabilize particles in the co-treated mixture via charge

327 neutralization and or "sweep-flocculation" mechanisms (Davis and Edwards, 2014).

328 However, co-treatment had no influence on particulate surface charge (Figure 1) which

329 indicates that charge neutralization was not significant. No change of particulate surface 330 charges can be explained by several factors. The experimental water chemistry (pH and Fe 331 concentration) was not favorable for adsorption-destabilization (charge neutralization) 332 mechanisms, as shown in Figure S5 (Johnson and Amirtharajah, 1983). Rather,

333 experimental conditions were more likely to have encouraged sweep flocculation, where 334 the kinetic energy of larger falling particles is adequate to overcome electrostatic surface 335 repulsive forces of suspended particles (Gregory and O'Melia, 1989). Additionally, NOM in 336 MWW exhibits coagulant demand, which likely dominates surface charge neutralization, 337 making destabilization even less favorable (Stumm and O'Melia, 1968). These elevated 338 concentrations of organic matter require increased coagulant doses compared with what 339 would typically be required to achieve destabilization (Fettig and Ratnaweera, 1993). 
340 Furthermore, the presence of $\mathrm{PO}_{4}{ }^{3-}$ likely impacted charge neutralization potential. $\mathrm{Fe}(\mathrm{III})$,

341 and other metals, have a strong affinity for available $\mathrm{PO}_{4}^{3-}$, and the majority of $\mathrm{PO}_{4}^{3-}$ would

342 need to be adsorbed and precipitated before Fe(III) would begin to destabilize suspended

343 MWW colloids (Tenney and Stumm, 1965). Higher AMD:MWW ratios would theoretically

344 provide increased particle destabilization, however these ratios were not studied

345 experimentally due to the perceived practical limits on WWTP capacity. pH modeling

346 demonstrates the addition of higher strength AMD will further suppress pH (SI S4), shifting

347 water chemistry into regions favorable for charge neutralization (Figure S5).

\subsection{Supernatant solids characterization}

Sludge settling was not significantly impacted by AMD co-treatment, with the

351 exception of the highest AMD addition ratio (Figure 2A). The highest AMD dose improved

352 settling by $20 \%$ over MWW-only, while other co-treatment conditions showed negligible

353 improvement. No settling is reported for the AMD as the discharge contained only small

354 and dissolved solids. The significant settling improvement noted at the highest AMD ratio

355 was not seen with the same significance in DI water at that same ratio, suggesting

356 improvement was not a function of dilution. Improved settling with increasing AMD ratio,

357 despite little change in surface charge, demonstrates sweep flocculation as the controlling

358 particle destabilization mechanism, in agreement with coagulation modeling (Figure S5). 


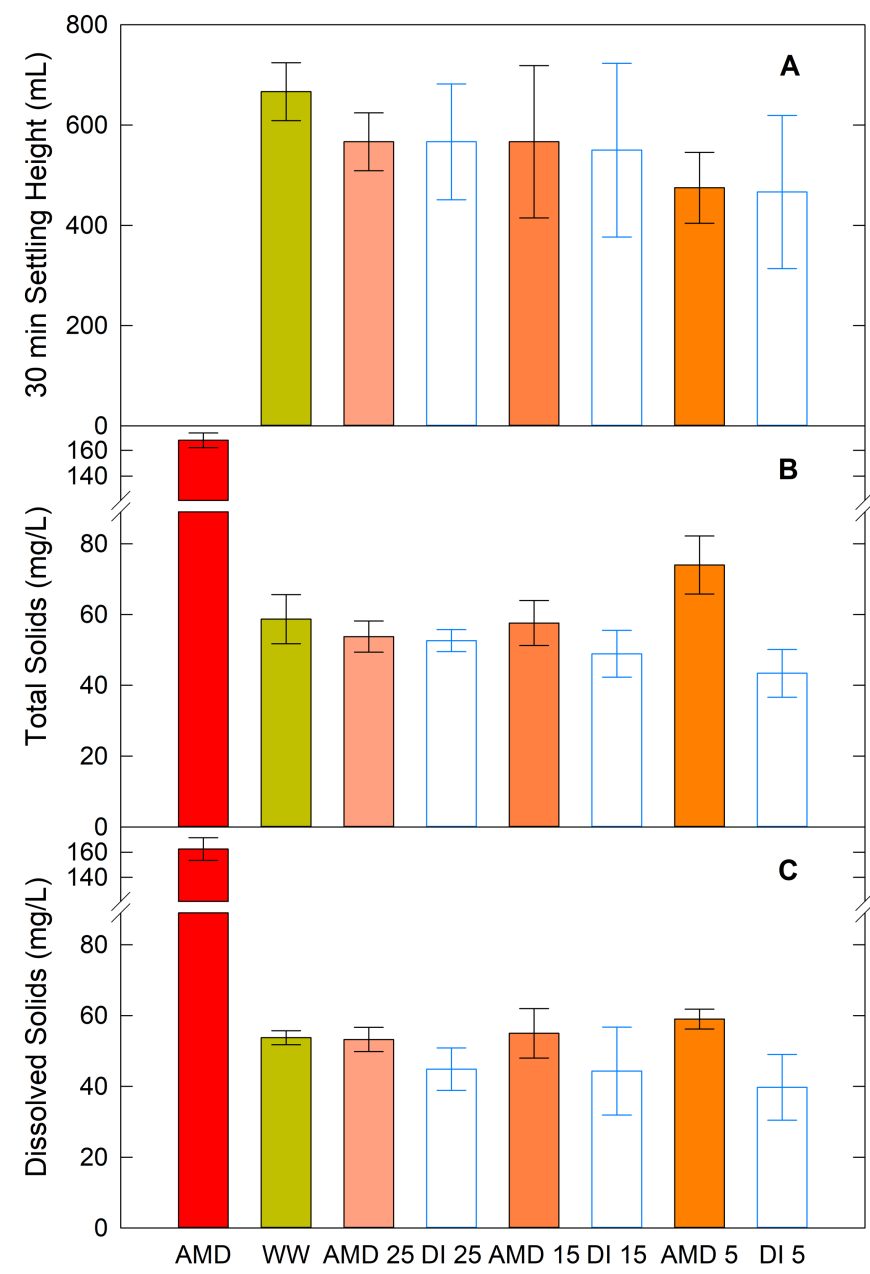

360 Figure 2: (A) Recorded sludge height in $\mathrm{mL}$ after $30 \mathrm{~min}$ of settling; (B) Experimentally 361 determined total solids remaining in supernatant; (C) Experimentally determined 362 dissolved solids remaining in supernatant

363 Co-treatment also had little influence on TS and TDS content (Figure 2B,C). The

364 AMD-only control contained nearly triple the amount of TS found in the MWW-only

365 control. Yet even in the AMD 1:5 samples the TS was only slightly higher (74 compared to

$36659 \mathrm{mg} / \mathrm{L}$ in the MWW-only control) and the TDS were nearly identical (59 vs $54 \mathrm{mg} / \mathrm{L}$ ).

367 Although TDS generally represents a minimal threat to aquatic organisms (when TDS <

368 1,000 mg/L, per Chapman et al., 2000), TDS concentration remains a significant water 
369 quality consideration. A relatively constant TDS concentration suggests AMD addition does

370 not significantly increase the effluent ionic strength, which is proportional to TDS (Kemp,

371 1971; Langelier, 1936). If the TDS and subsequent ionic strength were to have increased,

372 this could have decreased adsorption of $\mathrm{PO}_{4}{ }^{3-}$ onto $\mathrm{Fe}(\mathrm{III})$ and promote destabilization

373 (break up) of aggregates (Zhang et al., 2010; Zita and Hermansson, 1994). MWW can be co-

374 treated with high volumes of AMD without TDS being of concern.

375 Although some changes in solids concentration were experienced, both the TS and

376 TDS concentrations in all co-treatment trials were lower than what was predicted by mass

377 balance (Tables S1 \& S2). AMD 1:25 and 1:15 trials had 15\% fewer TS while the AMD 1:5

378 had just $\sim 10 \%$ less. A decrease in supernatant solids was likely a function of improved

379 coagulation by sweep flocculation, as discussed in section 3.1. An increased concentration

380 of settling solids would result in increased resultant sludge, in agreement with the minimal

381 changes seen in sludge blanket height (Figure 2A). TDS were proportional to the amount of

382 AMD added. As the AMD ratio increased, the amount of post-settling TDS was $9 \%$ to $24 \%$

383 less than predicted by mass balance calculations (e.g. 10-15 mg/L TDS). The majority of

384 this apparent loss in TDS corresponds to the mass of $\mathrm{PO}_{4}{ }^{3-}$ removed via adsorption onto $\mathrm{Fe}$ 385 particles (see Section 3.4).

The TSS values were not directly measured in this study, but approximated by

387 calculating the difference between the TDS and TS values. The WWTP influent TSS,

388 obtained from the facilities DEP/EPA reports, generally contains $166 \mathrm{mg} / \mathrm{L}$. All calculated

389 experimental TSS concentrations were below $15 \mathrm{mg} / \mathrm{L}$, within a typical NPDES permit

390 weekly TSS discharge limits of 40-50 mg/L (Environmental Protection Agency, 2019; EPA

391 Region 3, 2016). These results demonstrate co-treatment positively impacted MWW 
392 effluent solids and retained TSS removals (compared to influent) of over 90\%. It is

393 important to note TSS removal may have been influenced by experimental mixing

394 conditions. The velocity gradients generated during rapid mixing $\left(\mathrm{G}>100 \mathrm{sec}^{-1}\right)$ could have

395 caused orthokinetic flocculation (i.e. fluid shear), an increase in collision frequency

396 between suspended particles, resulting in larger flocs (Han and Lawler, 1992; Teh et al.,

397 2016). The noted improvement in TSS removal was likely a function of both orthokinetic

398 flocculation and differential sedimentation (i.e., sweep flocculation).

399

3.3. Co-treatment impacts on oxygen demand

Co-treatment had minimal impact on both BOD and COD of the MWW (Figure 3).

402 The COD remained relatively constant under all conditions. However, the average COD in 403 all AMD experiments was lower than theoretically determined values (Table S3, Equation 404 S3) by $\sim 10 \%$. The slight loss of COD suggests that there was some removal during the co405 treatment process. COD removal is likely a mechanism of either microbial-mediated 406 aggregation of organics resulting in bioflocculation, or through adsorption of biomaterial 407 onto Fe (Choo and Kang, 2003; Jimenez et al., 2007). BOD results were similar (Figure 3). 408 The BOD between all samples was similar relative to the MWW-only control, meaning co409 treatment did not further increase oxygen demand. This is an important operational 410 consideration as BOD is one of the most critical effluent water-quality parameters. 


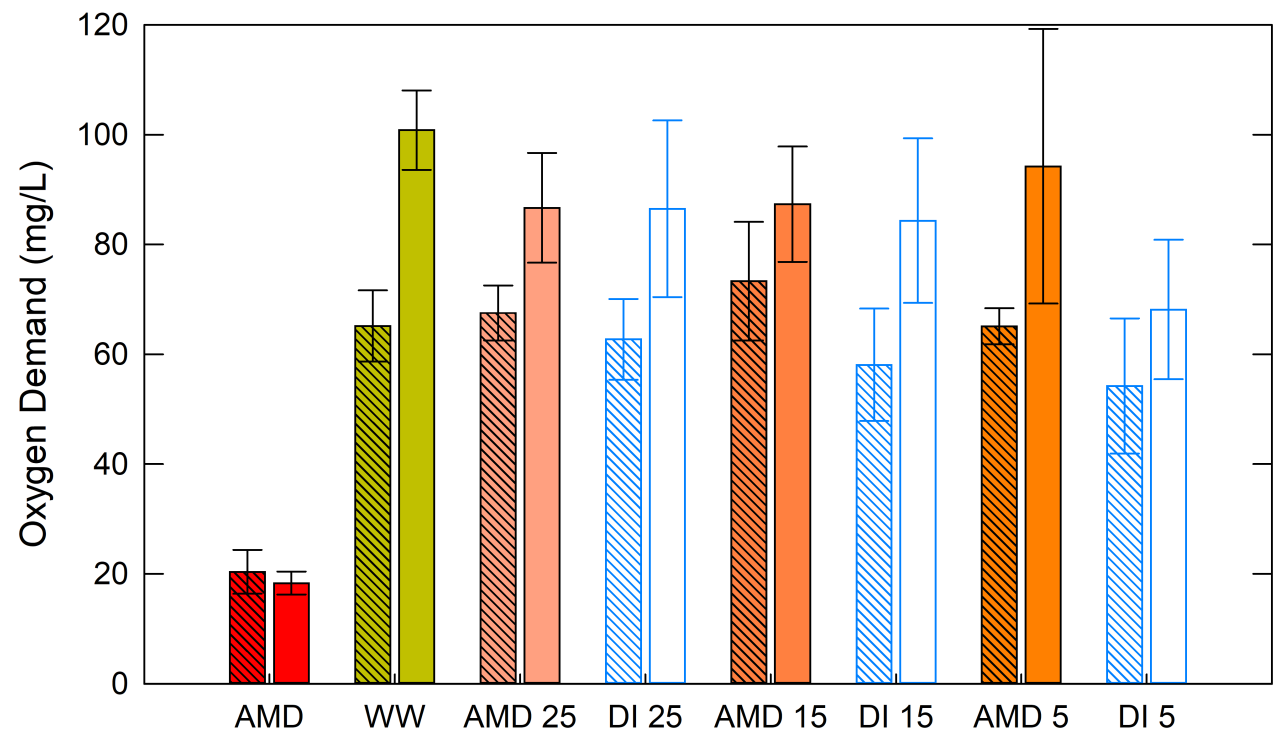

412 Figure 3: Oxygen demand remaining for each sample after treatment

3.4. Influence on ion concentrations

416 in the supernatant increased by $75 \%$ in the $1: 25$ treatment, $127 \%$ in the 1:15 treatment,

417 and $370 \%$ in the 1:5 treatment exceeding $260 \mathrm{mg} / \mathrm{L}$. However, this increase is not

418 problematic as $\mathrm{SO}_{4}{ }^{2-}$ concentrations are only slightly over the $250 \mathrm{mg} / \mathrm{L}$ allowable limit for

419 drinking water (40 CFR 143.3) and significantly below the $>2,000 \mathrm{mg} / \mathrm{L}$ value determined

420 necessary to be toxic to several freshwater fish (Soucek and Kennedy, 2005). If the AMD is

421 added prior to the biological treatment phase it is possible that increased $\mathrm{SO}_{4}^{2-}$ reduction

422 would take place and produce lower $\mathrm{SO}_{4}{ }^{2-}$ effluent concentrations (Lens et al., 1995). $\mathrm{SO}_{4}{ }^{2-}$

423 reducing bacteria have been shown to survive and adapt to high oxygen environments such

424 as in activated sludge systems and enable $\mathrm{SO}_{4}{ }^{2-}$ reduction (Kjeldsen et al., 2004). However,

425 this does not apply to all MWW microbe populations as not all activated sludge 
426 environments are conducive for sulfate reduction (Schramm et al., 1999). One potential

427 issue that could arise from increased $\mathrm{SO}_{4}{ }^{2-}$ reduction is the resultant sulfide (S)

428 concentrations that can disrupt floc formations and Fe-based coagulation processes by the

429 formation of FeS (Nielsen and Keiding, 1998).

$430 \quad$ Results from $\mathrm{PO}_{4}^{3-}$ analysis demonstrate the potential of co-treatment to

431 significantly decrease $\mathrm{PO}_{4}^{3-}$ (and total $\mathrm{P}$ ) concentrations in MWW (Figure 4A). Although

$432 \mathrm{PO}_{4}^{3-}$ exists as inorganic and organic forms in $\mathrm{MWW}$, the non-speciated total $\mathrm{PO}_{4}{ }^{3-}$ was

433 deemed sufficient for this study as typical MWW effluent discharge limits are set in terms

434 of total P. All three AMD ratios exhibited $\mathrm{PO}_{4}{ }^{3-}$ removal, with the 1:15 condition averaging

$435 \sim 84 \%$ decrease and the 1:5 trials averaging $>97 \%$ decrease, significantly improved over

436 the MWW control. DI trials showed no improvement over dilution alone. These results

437 support the use of AMD co-treatment as a lower cost alternative for tertiary treatment

438 focused on P-removal, especially in shrinking cities or other economically and

439 geographically disadvantaged areas. Decreasing P discharges into water where it is a

440 limiting nutrient is of increasing concern, globally, as a strategy to control harmful algal

441 blooms and eutrophication (Alexander et al., 2008; Anderson et al., 2008). 

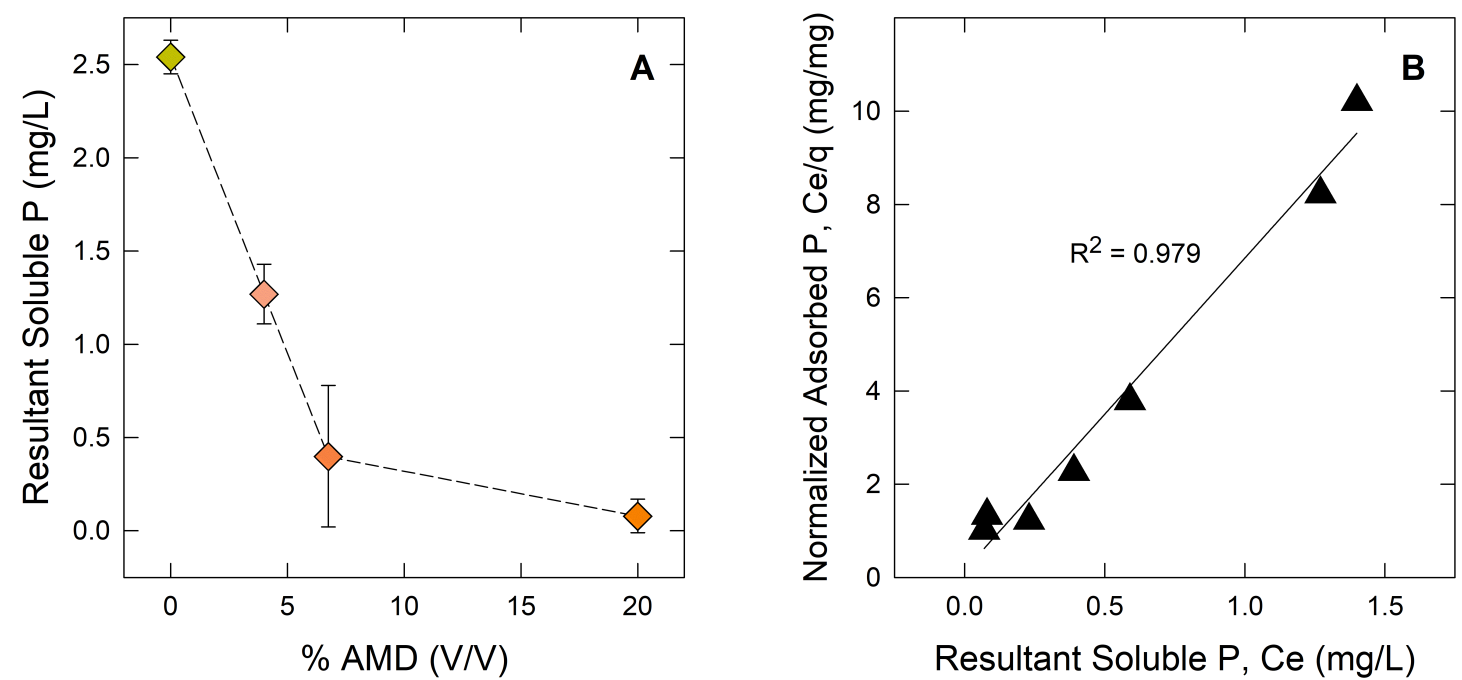

Figure 4: A) Total P concentrations remaining in each sample supernatants, measured

444 as $\mathrm{mg} / \mathrm{L} \mathrm{PO}_{4}$ on IC. Dashed line represents trend between experimental data points B)

445 Langmuir isotherm behavior of experimental data, demonstrating adsorption

446 mechanism of P removal. Further explanation in SI S5.

$447 \mathrm{PO}_{4}{ }^{3-}$ removal closely follows Langmuir isotherm behavior. The relative linearity $\left(\mathrm{R}^{2}=\right.$ 448 0.979) confirms that $\mathrm{PO}_{4}{ }^{3-}$ adsorption unto in situ AMD-generated Fe oxides is the 449 mechanism for nutrient removal in co-treatment (de-Bashan and Bashan, 2004; Kavanaugh 450 et al., 1978). $\mathrm{PO}_{4}^{3-}$ removal via adsorption further explain the streaming current and 451 settling results discussed in section 3.1, as $\mathrm{PO}_{4}{ }^{3-}$ adsorption unto $\mathrm{Fe}(\mathrm{III})$ drastically impedes 452 coagulation (Tenney and Stumm, 1965). Furthermore, the Langmuir relationship 453 quantified the maximum adsorption capacity of the co-treatment system as $0.15 \mathrm{mg}$ P per $454 \mathrm{mg}$ Fe added (0.46 $\mathrm{mg} \mathrm{PO}_{4}^{3-} / \mathrm{mg}$ Fe; see SI S5). 
Total Mn and $\mathrm{Al}$ in both the AMD and secondary MWW were low, making AMD Fe

458 the primary constituent of concern. Total Fe in AMD was $147 \mathrm{mg} / \mathrm{L}$ while there was little Fe

459 in the raw MWW (<2 mg/L). Settled, total Fe increased with increasing ratio to a maximum

460 of $21 \mathrm{mg} / \mathrm{L}$ (Figure 5). The majority of Fe was operationally defined as dissolved,

461 comprising $57 \%$ and $73 \%$ of the total Fe content in the AMD 1:15 and AMD 1:5,

462 respectively. This is similar to the raw AMD in which over $80 \%$ of Fe passed through the UF

463 membrane.

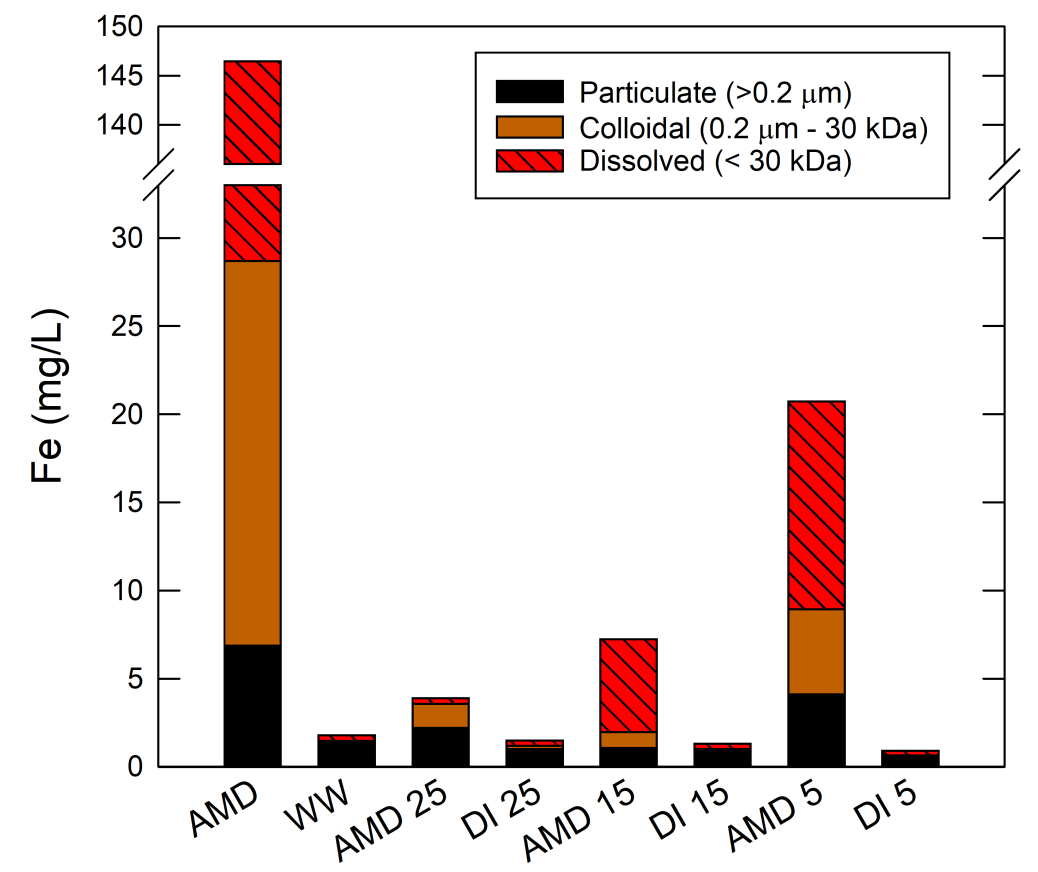

464

465 Figure 5: Fractionated iron content showing operationally defined particulate, colloidal and dissolved Fe. Bars represent the mean value for each of the three fractions

The amount of dissolved Fe is orders of magnitude higher than what would be

468 thermodynamically expected from an Fe(III) solubility diagram at pH 6.5 (Figure S5),

469 suggesting that operationally defined "dissolved" Fe is actually amorphous nanoscale 
$470 \mathrm{Fe}(\mathrm{III})$. This is supported by the stable colloidal conditions demonstrated by the streaming

471 current results (Figure 1, surface charge), where aggregation is expected to be quite

472 limited. The presence of $\mathrm{PO}_{4}{ }^{3-}$ during Fe precipitation can result in particles operationally

473 defined as dissolved despite thermodynamic predictions to the contrary (Jiang et al., 2015).

$474 \quad$ Mass balance calculations showed a significant portion of the Fe gravimetrically

475 separated with the sludge (see SI S7, Table S4). The fraction of total Fe removed from the

476 bulk solution ranged from $\sim 50 \%$ (AMD 1:25) down to $~ 30 \%$ in the AMD 1:5. The AMD

$477 \quad$ 1:15 ratio settled out approximately $38 \%$ of Fe added. Although AMD could have

478 contributed insoluble Fe(II) to the system (Watzlaf et al., 2004), this was unlikely under

479 experimental conditions. Since the solutions were open to the atmosphere, rapid mixed for

480 several minutes, and under circumneutral $\mathrm{pH}$, the oxygenation of Fe(II) to Fe(III) would

481 have quickly proceeded to equilibrium $\left(k=1.5-3.0 \times 10^{13} \mathrm{M}^{-2} \mathrm{~atm}^{-1} \mathrm{~min}^{-1}\right)$ (Davison and

482 Seed, 1983; Moses and Herman, 1989; Stumm and Lee, 1961). Under equilibrium

483 conditions at experimental pH, both Fe(II) solubility (O'Melia, 1973) and Fe redox potential

484 (pE) indicate high percentages of Fe(II) were unlikely. This low percentage of Fe settling

485 with MWW sludge was more likely a result of suspended, nanoscale Fe particles. The

486 approximate Stoke's law terminal settling velocities of these small $(<0.2 \mu \mathrm{m})$ particles are

487 no faster than $0.6 \mathrm{~cm} /$ day (assuming $\mathrm{T}=15^{\circ} \mathrm{C}$, $\rho_{\text {particle }}=4250 \mathrm{~kg} / \mathrm{m}^{3}$ ) meaning an

488 operationally longer settling time would not significantly improve Fe concentrations in

489 effluent. Although it is uncommon for WWTPs to have Fe discharge limits, removal of Fe is

490 important to maintain high effluent quality and decrease the total Fe load on the receiving

491 water body; however, the hypothetical co-treatment effluent Fe loading from supernatant 
492 produced in this study represents an order of magnitude improvement over an unabated 493 AMD discharge.

3.6. Co-treatment impact on microbial activity Co-treating MWW with AMD can impact the metabolism of activated sludge 497 microbes. In respirometric experiments where AMD was mixed with MWW (MLSS), BOD 498 consumption rates were impeded compared to trials where no AMD was added (Figure 6).

499 The respirometer reactors with no AMD added achieved a higher realized-BOD

500 consumption over the 4-hr period and consumed oxygen at a faster average rate than those 501 with AMD. There is also a much larger variance in the co-treatment reactors relative to the 502 narrow variation in the MLSS-only controls. Reactors with AMD consumed oxygen at a 503 slower rate initially, likely due to the stress induced by a perturbation in water quality. 504 Over the four hours, the MWW samples consumed oxygen $\left(\mathrm{O}_{2}\right)$ at an average rate of 3.5 $505 \mathrm{mg} / \mathrm{L}$ of $\mathrm{O}_{2}$ per hour $\left[\left(\mathrm{O}_{2}\right) / \mathrm{hr}\right]$ while the co-treated reactors consumed at only $1.9\left(\mathrm{O}_{2}\right) / \mathrm{hr}$. 506 In the first hour, oxygen consumption was nearly three times faster in reactors with only 507 MWW (i.e., $3.7\left(\mathrm{O}_{2}\right) / \mathrm{hr}$ in MWW reactors vs $1.2\left(\mathrm{O}_{2}\right) / \mathrm{hr}$ in AMD:MWW reactors). However, 508 the difference between the two sample rates began to decrease over time. During the last 509 hour the co-treated samples consumed $\mathrm{O}_{2}$ at a rate similar to the MWW samples, 5.5 vs 4.9 $510\left(\mathrm{O}_{2}\right) / \mathrm{hr}$. The $5.5\left(\mathrm{O}_{2}\right) / \mathrm{hr}$ is also the highest average hourly rate exhibited by any sample. 511 This suggests that the bacteria in co-treated samples had begun to acclimate. Acclimation 512 time at full-scale would be impacted by hydraulic residence time (4-8 hours), solids 513 retention time (3-15 days (Metcalf \& Eddy et al., 2013)), and sludge recycle rates. 


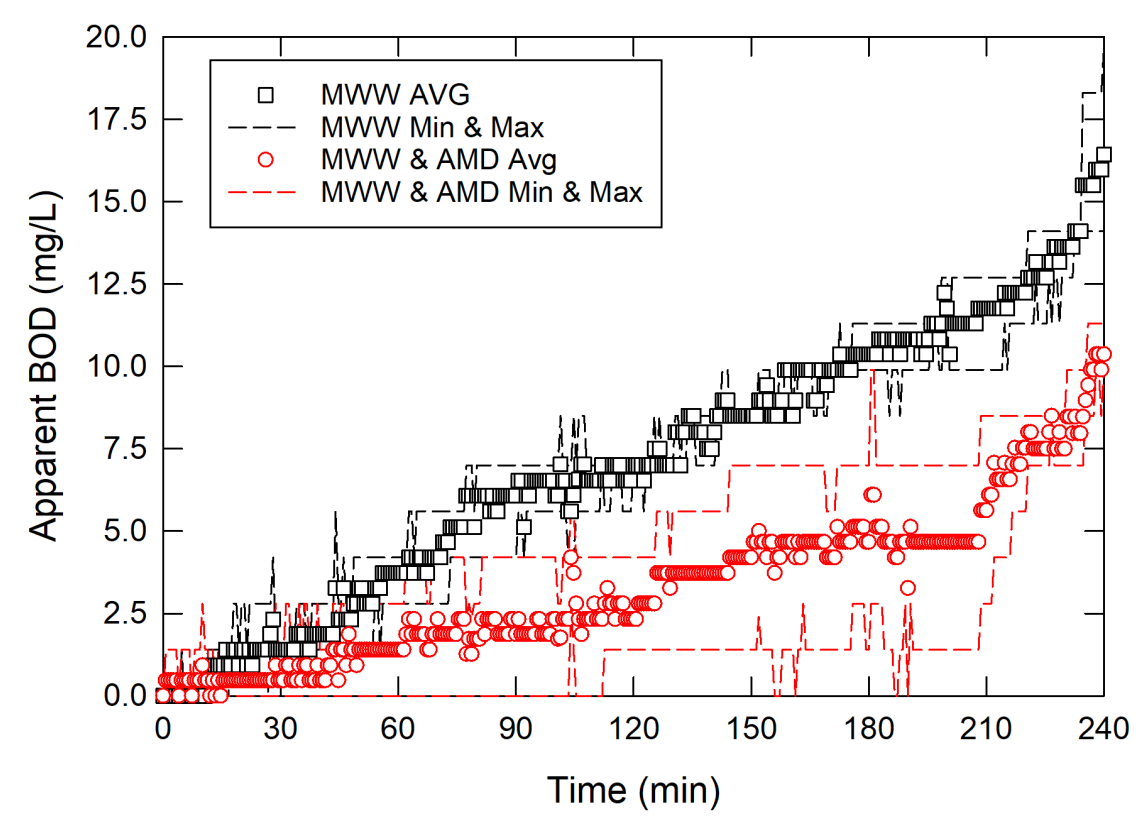

514

515 Figure 6: Respirometric BOD results, markers represent the mean value for each sample

516 type, and dashed line represent the corresponding highest and lowest measured value at

517 each point

518 Respirometric results also inform full-scale adaptation. Co-treating with AMD at

519 WWTPs with longer mean cell residence times would better accommodate cellular

520 acclimation upon initiation of $\mathrm{AMD}$ addition. The increased $\mathrm{O}_{2}$ consumption after 200

521 minutes in Figure 6 suggest microbial community adaptation to the addition of AMD,

522 without long-term negative impacts. Gradual increases in AMD:MWW ratio may improve

523 microbial adaptation. Although the reaction times (days compared to hours) and AMD

524 differed (Fe dominant versus various metals in excess), MWW bacteria in experiments by

525 Hughes and Gray (2012) behaved similarly, requiring an initial acclimation period after

526 addition of AMD with very different quality. Further assessment of microbial community

527 adaptation to AMD inputs over longer time scales should be a focus of future research. 
528

529

530

531

532 where differential settling is the primary mechanism for particle aggregation. Co-treatment

533 led to improved settling when the highest ratio was evaluated, despite extant repulsive

534 surface charges. However, this condition also yielded the highest effluent Fe loading.

535 Resulting supernatant Fe was nanoscale. Over 90\% removal of phosphate was

536 demonstrated, and described by Langmuir adsorption isotherm unto iron oxides. AMD co-

537 treatment represents a novel form of nutrient removal from wastewater effluents. Impact

538 on other studied wastewater quality parameters (TS, BOD, COD) broadly indicated

539 insignificant impact. In this way, co-treatment also represents a novel form of AMD

540 disposal. Introduction of AMD into activated sludge communities caused a short-term

541 decrease in oxygen consumption rate, with recovery noted after several hours, suggesting

542 adaptation. Further research on microbial community impacts is required. Ultimately, the

543 understanding of physio-chemical processes and other water quality results in this work

544 support the feasibility of full-scale co-treatment, which may be especially advantageous to

545 communities with declining MWW production.

\section{Declaration of Interests}

548 None.

\section{Acknowledgements}


551 This work was funded primarily by the Foundation for Pennsylvania Watersheds

552 (Alexandria, PA). Any views expressed in this work belong solely to the authors not the

553 funding agency. The authors also acknowledge laboratory contributions from James

554 Eckenrode, Kendra Zaruba, Lily Currie, and Ciaran Wesser of the Saint Francis University

555 Center for Watershed Research \& Service, as well as for access to water samples from the

556 Johnstown Dornick Point Wastewater Treatment plant and the Mattabassett District Water

557 Pollution Control facility. This is Contribution no. 1871 for the Belle W. Baruch Institute for

558 Marine and Costal Sciences. 
559

560

561

562

563

564

565

566

567

568

569

570

571

572

573

574

575

576

577

578

579

580

\section{References}

Akcil, A., Koldas, S., 2006. Acid Mine Drainage (AMD): causes, treatment and case studies. J. Clean. Prod. 14, 1139-1145. https://doi.org/10.1016/j.jclepro.2004.09.006

Alexander, R.B., Smith, R.A., Schwarz, G.E., Boyer, E.W., Nolan, J. V, Brakebill, J.W., 2008. Differences in Phosphorus and Nitrogen Delivery to The Gulf of Mexico from the Mississippi River Basin. Environ. Sci. Technol. 42, 822-830. https://doi.org/10.1021/es0716103

Anderson, D.M., Burkholder, J.M., Cochlan, W.P., Glibert, P.M., Gobler, C.J., Heil, C.A., Kudela, R.M., Parsons, M.L., Rensel, J.E.J., Townsend, D.W., Trainer, V.L., Vargo, G.A., 2008. Harmful algal blooms and eutrophication: Examining linkages from selected coastal regions of the United States. Harmful Algae 8, 39-53. https://doi.org/10.1016/j.hal.2008.08.017

APHA, 2012. Standard Methods for Examination of Water and Wastewater (Standard Methods for the Examination of Water and Wastewater). Am. Public Heal. Assoc. Washington, DC, USA. https://doi.org/ISBN 9780875532356

Azapagic, A., 2004. Developing a framework for sustainable development indicators for the mining and minerals industry. J. Clean. Prod. 12, 639-662. https://doi.org/10.1016/S0959-6526(03)00075-1

Carlson, K.H., Knocke, W.R., Gertig, K.R., 1997. Optimizing treatment through Fe and Mn fractionation. J. Am. Water Works Assoc. 89, 162-171. https://doi.org/10.1002/j.1551-8833.1997.tb08216.x

Chang, I.S., Shin, P.K., Kim, B.H., 2000. Biological treatment of acid mine drainage under 
sulphate-reducing conditions with solid waste materials as substrate. Water Res. 34, 1269-1277. https://doi.org/10.1016/S0043-1354(99)00268-7

Chapman, P.M., Bailey, H., Canaria, E., 2000. Toxicity of total dissolved solids associated with two mine effluents to chironomid larvae and early life stages of rainbow trout. Environ. Toxicol. Chem. 19, 210-214. https://doi.org/10.1002/etc.5620190125

Choo, K.-H., Kang, S.-K., 2003. Removal of residual organic matter from secondary effluent by iron oxides adsorption. Desalination 154, 139-146. https://doi.org/10.1016/S0011-9164(03)80014-0

Clark, T., Burgess, J.E., Stephenson, T., Arnold-Smith, A.K., 2000. The Influence of Iron-Based Co-Precipitants on Activated Sludge Biomass. Process Saf. Environ. Prot. 78, 405-410. https://doi.org/10.1205/095758200530916

Coulton, R., Bullen, C., Hallett, C., 2003. The design and optimisation of active mine water treatment plants. L. Contam. Reclam. 11, 273-279. https://doi.org/10.2462/09670513.825

Davis, C.C., Edwards, M.A., 2014. Coagulation with hydrolyzing metal salts: Mechanisms and water quality impacts. Crit. Rev. Environ. Sci. Technol. 44, 303-347. https://doi.org/10.1080/10643389.2012.718947

Davison, W., Seed, G., 1983. The kinetics of the oxidation of ferrous iron in synthetic and natural waters. Geochim. Cosmochim. Acta 47, 67-79. https://doi.org/10.1016/00167037(83)90091-1

de-Bashan, L.E., Bashan, Y., 2004. Recent advances in removing phosphorus from wastewater and its future use as fertilizer (1997-2003). Water Res. 38, 4222-4246. https://doi.org/10.1016/j.watres.2004.07.014 
604 De Freitas, J.M., Meneghini, R., 2001. Iron and its sensitive balance in the cell. Mutat. Res.

605 Mol. Mech. Mutagen. 475, 153-159. https://doi.org/10.1016/S0027-5107(01)00066-

$606 \quad 5$

607 Deng, D., Lin, L.-S., 2013. Two-stage combined treatment of acid mine drainage and

608 municipal wastewater. Water Sci. Technol. 67, 1000-1007.

609 https://doi.org/10.2166/wst.2013.653

610 Dentel, S.K., Thomas, A. V, Kingery, K.M., 1989. Evaluation of the streaming current

611 detector-I. Use in jar tests. Water Res. 23, 413-421. https://doi.org/10.1016/0043$612 \quad 1354(89) 90132-2$

613 Dodds, W., Smith, V., 2016. Nitrogen, phosphorus, and eutrophication in streams. Inl.

614 Waters 6, 155-164. https://doi.org/10.5268/IW-6.2.909

615 Dominguez, D., Gujer, W., 2006. Evolution of a wastewater treatment plant challenges

616 traditional design concepts. Water Res. 40, 1389-1396. https://doi.org/10.1016/j.watres.2006.01.034

618 Environmental Protection Agency, 2019. National Pollutant Discharge Elimination System (NPDES) [WWW Document]. URL https://www.epa.gov/npdes

620 EPA Region 3, 2016. Region 3 NPDES Permit Quality Review: Pennsylvania. Philadelphia, 621

622 Evangelou, V.P. (Bill), Zhang, Y.L., 1995. A review: Pyrite oxidation mechanisms and acid mine drainage prevention. Crit. Rev. Environ. Sci. Technol. 25, 141-199. https://doi.org/10.1080/10643389509388477 Management in Shrinking Cities. Public Work. Manag. Policy 21, 128-156. 
https://doi.org/10.1177/1087724X15606737

628

629

630

631

632

633

634

635

636

637

638

639

640

641

642

643

644

645

646

647

648

649

Feng, Q., Li, T., Qian, B., Zhou, L., Gao, B., Yuan, T., 2014. Chemical Characteristics and Utilization of Coal Mine Drainage in China. Mine Water Environ. 33, 276-286. https://doi.org/10.1007/s10230-014-0271-y

Fettig, J., Ratnaweera, H., 1993. Influence of Dissolved Organic Matter on Coagulation/Flocculation of Wastewater by Alum. Water Sci. Technol. 27, 103-112. https://doi.org/10.2166/wst.1993.0269

Goodwill, J.E., Jiang, Y., Reckhow, D.A., Gikonyo, J., Tobiason, J.E., 2015. Characterization of particles from ferrate preoxidation. Environ. Sci. Technol. 49, 4955-4962. https://doi.org/10.1021/acs.est.5b00225

Goodwill, J.E., Labar, J., Slovikosky, D., Strosnider, W.H.J., 2019. Preliminary Assessment of Ferrate Treatment of Metals in Acid Mine Drainage. J. Environ. Qual. 1-34. https://doi.org/10.2134/jeq2019.02.0079

Gray, N.F., 1998. Acid mine drainage composition and the implications for its impact on lotic systems. Water Res. 32, 2122-2134. https://doi.org/10.1016/S0043$1354(97) 00449-1$

Gregory, J., O’Melia, C.R., 1989. Fundamentals of flocculation. Crit. Rev. Environ. Control 19, 185-230. https://doi.org/10.1080/10643388909388365

Han, M., Lawler, D.F., 1992. (Relative) insignificance of G in flocculation. J. / Am. Water Work. Assoc. 84, 79-91. https://doi.org/10.1002/j.1551-8833.1992.tb05869.x

Harper, D., 1992. What is eutrophication?, in: Eutrophication of Freshwaters. Springer Netherlands, Dordrecht, pp. 1-28. https://doi.org/10.1007/978-94-011-3082-0_1 He, C., Zhang, T., Vidic, R.D., 2016. Co-treatment of abandoned mine drainage and Marcellus 
650

651

652

653

654

655

656

657

658

659

660

661

662

663

664

665

666

667

668

669

670

671

672

Shale flowback water for use in hydraulic fracturing. Water Res. 104, 425-431. https://doi.org/10.1016/j.watres.2016.08.030

Hedin, R.S., Nairn, R.W., Kleinmann, R.L.P., 1994. Passive treatment of coal mine drainage, Infromation Circular 9389.

Herlihy, A.T., Kaufmann, P.R., Mitch, M.E., Brown, D.D., 1990. Regional estimates of acid mine drainage impact on streams in the mid-atlantic and Southeastern United States. Water. Air. Soil Pollut. 50, 91-107. https://doi.org/10.1007/BF00284786

Hughes, T.A., Gray, N.F., 2013a. Removal of Metals and Acidity from Acid Mine Drainage Using Municipal Wastewater and Activated Sludge. Mine Water Environ. 32, 170-184. https://doi.org/10.1007/s10230-013-0218-8

Hughes, T.A., Gray, N.F., 2013b. Co-treatment of acid mine drainage with municipal wastewater: Performance evaluation. Environ. Sci. Pollut. Res. 20, 7863-7877. https://doi.org/10.1007/s11356-012-1303-4

Jacobs, J.A., Lehr, J.H., Testa, S.M., 2014. Acid Mine Drainage, Rock Drainage, and Acid Sulfate Soils: Causes, Assessment, Prediction, Prevention, and Remediation, Acid Mine Drainage, Rock Drainage, and Acid Sulfate Soils: Causes, Assessment, Prediction, Prevention, and Remediation. https://doi.org/10.1002/9781118749197

Jia, W., Wang, Q., Zhang, J., Yang, W., Zhou, X., 2016. Nutrients removal and nitrous oxide emission during simultaneous nitrification, denitrification, and phosphorus removal process: effect of iron. Environ. Sci. Pollut. Res. 23, 15657-15664. https://doi.org/10.1007/s11356-016-6758-2

Jiang, Y., Goodwill, J.E., Tobiason, J.E., Reckhow, D.A., 2015. Effect of Different Solutes, Natural Organic Matter, and Particulate Fe(III) on Ferrate(VI) Decomposition in 
673

674

675

676

677

678

679

680

681

682

683

684

685

686

687

688

689

690

691

692

693

694

695

Aqueous Solutions. Environ. Sci. Technol. 49, 2841-2848. https://doi.org/10.1021/es505516w

Jimenez, J.A., La Motta, E.J., Parker, D.S., 2007. Effect of Operational Parameters on the Removal of Particulate Chemical Oxygen Demand in the Activated Sludge Process. Water Environ. Res. 79, 984-990. https://doi.org/10.2175/106143007x175717

Johnson, B.D., 2003. Chemical and Microbiological Characteristics of Mineral Spoils and Drainage Waters at Abandoned Coal and Metal Mines. Water, Air Soil Pollut. Focus 3, 47-66. https://doi.org/10.1023/A:1022107520836

Johnson, D.B., Hallberg, K.B., 2005. Acid mine drainage remediation options: a review. Sci. Total Environ. 338, 3-14. https://doi.org/10.1016/j.scitotenv.2004.09.002

Johnson, K.L., Younger, P.L., 2006. The co-treatment of sewage and mine waters in aerobic wetlands. Eng. Geol. 85, 53-61. https://doi.org/10.1016/j.enggeo.2005.09.026

Johnson, P.N., Amirtharajah, A., 1983. Ferric chloride and alum as single and dual coagulants. J. Am. Water Works Assoc. 75, 232-239. https://doi.org/10.1002/j.15518833.1983.tb05122.x

Karapanagioti, H.K., Atalay, A., 1996. Adsorption of Acid Mine Drainage Metals on Fly Ash. J. Am. Soc. Min. Reclam. 1996, 659-670. https://doi.org/10.21000/jasmr96010659

Kavanaugh, M.C., Krejci, V., Weber, T., Eugster, J., Roberts, P. V., 1978. Phosphorus Removal by Post-Precipitation with Fe(III). J. (Water Pollut. Control Fed. 50, 216-233.

Kemp, P.H., 1971. Chemistry of natural waters-I. Water Res. 5, 297-311. https://doi.org/10.1016/0043-1354(71)90175-8

Kjeldsen, K.U., Joulian, C., Ingvorsen, K., 2004. Oxygen Tolerance of Sulfate-Reducing Bacteria in Activated Sludge. Environ. Sci. Technol. 38, 2038-2043. 
https://doi.org/10.1021/es034777e

697

698

699

700

701

702

703

704

705

706

707

708

709

710

711

712

713

714

715

716

717

718

Kruse, N.A., Reber, R., Schlater, N., Spencer, R., Steinmaus, M., Imhoff, D., 2019. In stream dynamics of acid mine drainage and untreated sewage. Environ. Earth Sci. 78, 659. https://doi.org/10.1007/s12665-019-8680-7

Labrenz, M., Banfield, J.F., 2004. Sulfate-Reducing Bacteria-Dominated Biofilms That Precipitate ZnS in a Subsurface Circumneutral-pH Mine Drainage System. Microb. Ecol. 47, 205-217. https://doi.org/10.1007/s00248-003-1025-8

Langelier, W.F., 1936. The Analytical Control of Anti-Corrosion Water Treatment. J. Am. Water Works Assoc. 28, 1500-1521. https://doi.org/10.1002/j.15518833.1936.tb13785.x

Lens, P.N., De Poorter, M.P., Cronenberg, C.C., Verstraete, W.H., 1995. Sulfate reducing and methane producing bacteria in aerobic wastewater treatment systems. Water Res. 29, 871-880. https://doi.org/10.1016/0043-1354(94)00195-D

Madzivire, G., Gitari, W.M., Vadapalli, V.R.K., Ojumu, T. V., Petrik, L.F., 2011. Fate of sulphate removed during the treatment of circumneutral mine water and acid mine drainage with coal fly ash: Modelling and experimental approach. Miner. Eng. 24, 1467-1477. https://doi.org/10.1016/j.mineng.2011.07.009

McCullough, C.D., Lund, M.A., May, J.M., 2008. Field-scale demonstration of the potential for sewage to remediate acidic mine waters. Mine Water Environ. 27, 31-39. https://doi.org/10.1007/s10230-007-0028-y

Metcalf \& Eddy, I., Tchobanoglous, G., Stensel, H.D., Tsuchihashi, R., Burton, F., 2013. Wastewater Engineering: Treatment and Resource Recovery, 5th ed. McGraw-Hill Education, New York, NY. 
719 Mitsch, W.J., Wise, K.M., 1998. Water quality, fate of metals, and predictive model validation

720 of a constructed wetland treating acid mine drainage. Water Res. 32, 1888-1900.

721 https://doi.org/10.1016/S0043-1354(97)00401-6

722 Moses, C.O., Herman, J.S., 1989. Homogeneous oxidation kinetics of aqueous ferrous iron at

723 circumneutral pH. J. Solution Chem. 18, 705-725.

724 https://doi.org/10.1007/BF00651804

725 Nielsen, P.H., Keiding, K., 1998. Disintegration of activated sludge flocs in presence of 726 sulfide. Water Res. 32, 313-320. https://doi.org/10.1016/S0043-1354(97)00235-2

727 O'Melia, C.R., 1973. Coagulation and Flocculation, in: Weber Jr., W.J. (Ed.), Physicochemical 728 Processes for Water Quality Control. John Wiley \& Sons, Ltd, New York, NY, pp. 101729103.

730 Oikonomidis, I., Burrows, L.J., Carliell-Marquet, C.M., 2010. Mode of action of ferric and 731 ferrous iron salts in activated sludge.J. Chem. Technol. Biotechnol. 85, 1067-1076. 732 https://doi.org/10.1002/jctb.2399

733 Ong, S.-A., Toorisaka, E., Hirata, M., Hano, T., 2010. Adsorption and toxicity of heavy metals 734 on activated sludge. ScienceAsia 36, 204. https://doi.org/10.2306/scienceasia1513$735 \quad 1874.2010 .36 .204$

736 Philips, S., Rabaey, K., Verstraete, W.H., 2003. Impact of iron salts on activated sludge and 737 interaction with nitrite or nitrate. Bioresour. Technol. 88, 229-239.

$738 \quad$ https://doi.org/10.1016/S0960-8524(02)00314-0

739 Pukelsheim, F., 1994. The Three Sigma Rule. Am. Stat. 48, 88.

$740 \quad$ https://doi.org/10.2307/2684253

741 Ren, S., Frymier, P.D., 2005. Toxicity of metals and organic chemicals evaluated with 
bioluminescence assays. Chemosphere 58, 543-550. https://doi.org/10.1016/j.chemosphere.2004.07.005

Ruihua, L., Lin, Z., Tao, T., Bo, L., 2011. Phosphorus removal performance of acid mine drainage from wastewater. J. Hazard. Mater. 190, 669-676. https://doi.org/10.1016/j.jhazmat.2011.03.097

Rybczynski, W., Linneman, P.D., 1999. How to save our shrinking cities. Public Interest 3044.

Scaglione, D., Caffaz, S., Ficara, E., Malpei, F., Lubello, C., 2008. A simple method to evaluate the short-term biogas yield in anaerobic codigestion of was and organic wastes. Water Sci. Technol. 58, 1615-1622. https://doi.org/10.2166/wst.2008.502

Schilling, J., Logan, J., 2008. Greening the rust belt: A green infrastructure model for right sizing America's shrinking cities. J. Am. Plan. Assoc. 74, 451-466. https://doi.org/10.1080/01944360802354956

Schramm, A., Santegoeds, C.M., Nielsen, H.K., Ploug, H., Wagner, M., Pribyl, M., Wanner, J., Amann, R., De Beer, D., 1999. On the occurrence of anoxic microniches, denitrification, and sulfate reduction in aerated activated sludge. Appl. Environ. Microbiol. 65, 41894196.

Sezgin, M., Jenkins, D., Parker, D.S., 1978. A unified theory of filamentous activated sludge bulking. J. Water Pollut. Control Fed. 50, 362-381.

Singer, P.C., Stumm, W., 1970. Acidic Mine Drainage: The Rate-Determining Step. Science (80-. ). 167, 1121-1123. https://doi.org/10.1126/science.167.3921.1121

Smith, V.H., 2003. Eutrophication of freshwater and coastal marine ecosystems a global problem. Environ. Sci. Pollut. Res. 10, 126-139. 
https://doi.org/10.1065/espr2002.12.142

766

767

768

769

770

771

772

773

774

775

776

777

778

779

780

781

782

783

784

785

786

787

Soucek, D.J., Kennedy, A.J., 2005. Effects of hardness, chloride, and acclimation on the acute toxicity of sulfate to freshwater invertebrates. Environ. Toxicol. Chem. 24, 1204. https://doi.org/10.1897/04-142.1

Spanjers, H., Vanrolleghem, P., 1995. Respirometry as a tool for rapid characterization of wastewater and activated sludge. Water Sci. Technol. 31, 105-114. https://doi.org/10.1016/0273-1223(95)00184-0

Strosnider, W.H.J., Nairn, R.W., 2010. Effective passive treatment of high-strength acid mine drainage and raw municipal wastewater in Potosí, Bolivia using simple mutual incubations and limestone. J. Geochemical Explor. 105, 34-42. https://doi.org/10.1016/j.gexplo.2010.02.007

Strosnider, W.H.J., Nairn, R.W., Peer, R.A.M., Winfrey, B.K., 2013. Passive co-treatment of Znrich acid mine drainage and raw municipal wastewater. J. Geochemical Explor. 125, 110-116. https://doi.org/10.1016/j.gexplo.2012.11.015

Strosnider, W.H.J., Winfrey, B.K., Nairn, R.W., 2011. Biochemical oxygen demand and nutrient processing in a novel multi-stage raw municipal wastewater and acid mine drainage passive co-treatment system. Water Res. 45, 1079-1086. https://doi.org/10.1016/J.WATRES.2010.10.026

Stumm, W., Lee, G.F., 1961. Oxygenation of Ferrous Iron. Ind. Eng. Chem. 53, 143-146. https://doi.org/10.1021/ie50614a030

Stumm, W., Morgan, J.J., 1996. Aquatic Chemistry: Chemical Equilibria and Rates in Natural Waters, Aquatic Chemistry: Chemical Equilibria and Rates in Natural Waters. Wiley.

Stumm, W., O’Melia, C.R., 1968. Stoichiometry of Coagulation. J. Am. Water Works Assoc. 60, 
514-539. https://doi.org/10.1002/j.1551-8833.1968.tb03579.x

\section{9}

790

791

792

793

794

795

796

797

798

799

800

801

802

803

804

805

806

807

808

809

810

Teh, C.Y., Budiman, P.M., Shak, K.P.Y., Wu, T.Y., 2016. Recent Advancement of CoagulationFlocculation and Its Application in Wastewater Treatment. Ind. Eng. Chem. Res. 55, 4363-4389. https://doi.org/10.1021/acs.iecr.5b04703

Ten State Standards, 2014. Recommended Standards for Wastewater Facilities. Albany, NY.

Tenney, M.W., Stumm, W., 1965. Chemical flocculation of microorganisms in biological waste treatment. J. Water Pollut. Control Fed. 37, 1370-1388.

Todd, A.S., Manning, A.H., Verplanck, P.L., Crouch, C., McKnight, D.M., Dunham, R., 2012. Climate-Change-Driven Deterioration of Water Quality in a Mineralized Watershed. Environ. Sci. Technol. 46, 9324-9332. https://doi.org/10.1021/es3020056

Warrender, R., Pearce, N.J.G., Perkins, W.T., Florence, K.M., Brown, A.R., Sapsford, D.J., Bowell, R.J., Dey, M., 2011. Field Trials of Low-cost Reactive Media for the Passive Treatment of Circum-neutral MetalMine Drainage in Mid-Wales, UK. Mine Water Environ. 30, 82-89. https://doi.org/10.1007/s10230-011-0150-8

Watzlaf, G.R.G., Schroeder, K.K.T., Kleinmann, R.L.P., Kairies, C.L., Nairn, R.W., 2004. The Passive Treatment of Coal Mine Drainage, ... States Department of .... Pittsburgh, PA.

Wei, X., Viadero, R.C., Bhojappa, S., 2008. Phosphorus removal by acid mine drainage sludge from secondary effluents of municipal wastewater treatment plants. Water Res. 42 , 3275-3284. https://doi.org/10.1016/j.watres.2008.04.005

Winfrey, B.K., Strosnider, W.H.J., Nairn, R.W., Strevett, K.A., 2010. Highly effective reduction of fecal indicator bacteria counts in an ecologically engineered municipal wastewater and acid mine drainage passive co-treatment system. Ecol. Eng. 36, 1620-1626. https://doi.org/10.1016/j.ecoleng.2010.06.025 
811 Yang, Y., Zhao, Y.Q., Babatunde, A.O., Wang, L., Ren, Y.X., Han, Y., 2006. Characteristics and 812 mechanisms of phosphate adsorption on dewatered alum sludge. Sep. Purif. Technol. 813 51, 193-200. https://doi.org/10.1016/j.seppur.2006.01.013

814 Younger, P.L., Henderson, R., 2014. Synergistic wetland treatment of sewage and mine 815 water: Pollutant removal performance of the first full-scale system. Water Res. 55, 7482. https://doi.org/10.1016/j.watres.2014.02.024

817 Yuan, L., Zhi, W., Liu, Y., Karyala, S., Vikesland, P.J., Chen, X., Zhang, H., 2015. Lead Toxicity to 818 the Performance, Viability, And Community Composition of Activated Sludge 819 Microorganisms. Environ. Sci. Technol. 49, 824-830. https://doi.org/10.1021/es504207c

821 Zhang, T., Ding, L., Ren, H., Guo, Z., Tan, J., 2010. Thermodynamic modeling of ferric 822 phosphate precipitation for phosphorus removal and recovery from wastewater. J. 823 Hazard. Mater. 176, 444-450. https://doi.org/10.1016/j.jhazmat.2009.11.049

824 Ziemkiewicz, P.F., Skousen, J.G., Brant, D.L., Sterner, P.L., Lovett, R.J., Skousen, J.G., Sterner, 825 P.L., Lovett, R.J., 1997. Acid Mine Drainage Treatment with Armored Limestone in 826 Open Limestone Channels. J. Environ. Qual. 26, 1017.

827 https://doi.org/10.2134/jeq1997.00472425002600040013x

828 Zita, A., Hermansson, M., 1994. Effects of ionic strength on bacterial adhesion and stability 829 of flocs in a wastewater activated sludge system. Appl. Environ. Microbiol. 60, 3041$330 \quad 3048$. 